\title{
PRAKTIK PERIKLANAN ONLINE TERHADAP TESTIMONI PRODUK PELANGSING DALAM PERSPEKTIF UNDANG-UNDANG NOMOR 8 TAHUN 1999 TENTANG PERLINDUNGAN KONSUMEN DAN ETIKA BISNIS

\author{
(STUDI KASUS TERHADAP PRODUK PELANGSING HINDI 7 DAYS DAN JOYJUS
} FIBER PADA APLIKASI INSTAGRAM)
}

\author{
Meirza Aulia Chairani, S,H., M.H ${ }^{1}$ Trinah Asi Islami, S.H., M.H²
}

${ }^{1}$ Program Studi Ilmu Hukum, Universitas Merdeka Madiun, Alamat Jalan Serayu No. 79, Kota Madiun, Kode Pos 63133,E-mail: meirza.aulia@unmer-madiun.ac.id

${ }^{2}$ Program Studi Hukum Ekonomi Syari'ah, Fakultas Agama Islam, Universitas Hasyim Asy'ari Tebuireng Jombang, Alamat Jalan Irian Jaya 55 Tebuireng Jombang, Kode Pos 61471, E-mail: trinahislami@ unhasy.ac.id

\begin{abstract}
Online trading in the industrial era 4.0 is a trading method that is very popular with consumers. In addition to an easy, fast and practical process, of course online trading also has several weaknesses, including manipulation of advertising, which in fact the image contained in the advertisement does not match the real product. This is often found by consumers who use e-commerce trading systems. One of them is in the case of testimonials of Hindi 7 days slimming products and Joyjus Fiber which advertises their products through social media in the form of the Instagram application, where the two products upload testimonials with images and words in the same advertisement even though the two products are different business actors. The method used in this research is legal research using a statutory approach, conceptual approach and case studies taken from real cases on Hindi 7 days slimming products and Joyjus Fiber. Related to the type of research used in this research is normative juridical research and empirical juridical research.
\end{abstract}

Keywords : Online Advertising, Testimonials, Consumer Protection Law, Business Ethics

\section{PENDAHULUAN}

Perkembangan teknolgi yang semakin pesat membuat roda perekonomian juga semakin pesat. Mobilitas manusia sebagai manusia sosial untuk memenuhi kebutuhannya tidak bisa lepas dari orang lain. Manusia dengan manusia lainnya saling membutuhkan untuk memenuhi kebutuhan hidupnya. Pemenuhan kebutuhan tersebut dengan melakukan perdagangan barang untuk memenuhi kebutuhan hidup.

Perkembangan teknologi membuat mempermudah perdagangan melalui sarana internet. Pelaku usaha dan konsumen semakin terbantu adanya internet yang dapat mempermudah dalam melakukan transaksi jual beli. Adanya Covid 19 ini menjadikan konsumen untuk melakukan transaksi jual beli online melalui $e$-commerce yang terdapat di gadgetnya tanpa harus keluar rumah menuju pasar dan swalayan. 
Kemajuan teknologi pelaku usaha dapat sangat mudah untuk mempromosikan barang dan/atau jasa kepada konsumen dengan berbagai macam media informasi. Produk-produk yang beragam di jual penjual untuk menarik konsumen berbagai macam. Mulai dengan gambar yang menarik, video yang menarik dan kadang kala menggunakan artis atau influencer endorse untuk menarik konsumen. Hal ini digunakan pelaku usaha untuk menarik konsumen untuk datang ke tokonya. Namun ada beberapa pelaku usaha yang melakukan perbuatan yang mengambil foto atau testimoni dari toko lainnya digunakan untuk produk yang dijualnya.

Disisi lain, kondisi dan fenomena tersebut dapat mengakibatkan kedudukan pelaku usaha dan konsumen menjadi tidak seimbang, sebab konsumen dapat menjadi obyek aktifitas bisnis dari pelaku usaha melalui cara penjualan dengan iklan, promosi, serta penerapan janji standar yang merugikan konsumen. Hal ini disebabkan karena kurangnya pendidikan dan pengetahuan konsumen dan rendahnya kesadaran akan hak-hak dan kewajiban. ${ }^{1}$

Iklan dalam testimoni di upload di toko onlinenya seakan-akan testimoni tersebut berasal dari pelanggannya yang membeli produk di tokonya. Salah satu contoh produk pelangsing Hindi 7 days dan Joyjus Fiber mempunyai testimoni yang sama hanya merubah nama tokonya saja. Hal ini dapat merugikan konsumen jika membeli produk di toko tersebut.

Undang-Undang No 8 Tahun 1999 tentang Perlindungan Konsumen (selanjutnya disebut UU PK) sudah memberikan batasan bagi pelaku usaha dalam melakukan pengiklanan dan dilarang memproduksi, mempergunakan iklan yang menyesatkan dalam memproduksi barang dan/atau jasanya. Iklan yang menjelaskan produknya dengan jujur, jelas dan bertanggung jawab namun tidak dilaksanakan oleh pelaku usaha merugikan konsumen pada saat konsumen mengkonsumsinya.

Bahwa iklan tidak boleh mencantumkan kata-kata "aman", "tidak berbahaya", atau "bebas resiko" tanpa disertakan keterangan lengkap yang menyertainya. ${ }^{2}$ Posisi yang tidak berimbang antar pelaku usaha dan konsumen akan mudah disalahgunakan oleh pihak yang lebih kuat dan posisi dominan. ${ }^{3}$ gambar yang di upload di media sosial dan website produk-produk pelangsing ini dibuat semenarik mungkin dengan gambar, warna, dan tulisan dengan produk berbeda testimoni yang sama.

Berdasarkan pemaparan latar belakang tersebut para penulis tertarik untuk mengemukakan rumusan masalah antara lain sebagai beriku :

1.Bagaimana praktik periklanan testimoni Hindi 7 days dan Joyjus Fiber dalam media online Instagram?

2.Bagaimana analisis yuridis hukum perlindungan konsumen dan etika bisnis terhadap praktik periklanan testimoni Hindi 7 days dan Joyjus Fiber dalam media online instagram?

\section{METODE PENELITIAN}

Metode penulisan dalam penelitian ini menggunakan penelitian yuridis normatif (Normative legal research) dan penelitian yuridis empiris (Empirical legal research). Pendekatan masalah yang digunakan dalam penelitian ini menggunakan pendekatan Perundang-undangan (Statute Approach) dan Pendekatan Konseptual (conceptual approach), dan Studi kasus (case study). Bahan hukum primer merupakan bahan hukum yang bersifat autoritatif, artinya mempunyai otoritas. Bahan hukum primer terdiri dari perundang-undangan, catatan-catatan resmi atau risalah dalam pembuatan undang-undang dan putusan-putusan hakim. ${ }^{4}$ Adapun bahan hukum primer yang digunakan dalam penelitian ini antara lain:

1. Undang-Undang Perlindungan Kosumen Nomor 8 Tahun 1999 tentang Perlindungan Konsumen ( Tambahan Lembaran Negara Republik Indonesia Nomor 3821);

2. Undang-Undang Nomor 19 Tahun 2006 tentang Perubahan Undang-Undang Nomor 11 Tahun 2008 tentang Transaksi elektronik (Tambahan Lembaran Negara Republik Indonesia Nomor 5952);

3. Peraturan Pemerintah Nomor 58 Tahun 2001 tentang Pembinaan dan Pengawasan Penyelenggaraan Perlindungan Konsumen.

${ }^{1}$ Susanti Adi Nugroho, Proses Penyelesaian Sengketa Konsumen Ditinjau dari Hukum Acara Seraya Kendala Implementasinta, Kencana, Jakarta, 2011, h. 1

2 Celina Tri Siwi Kristiyanti, Hukum Perlindungan Konsumen, Sinar Grafika, Jakarta, 2009, h. 135

${ }^{3}$ Ibid, h, 135

${ }^{4}$ Peter Mahmud Marzuki, Penelitian Hukum (Edisi Revisi), PT. Adhitya Andrebina Agung, Jakarta,2015, h. 
Website : http://yustisia.unmermadiun.ac.id/index.php/yustisia

Sedangkan bahan hukum sekunder semua publikasi tentang hukum meliputi buku-buku teks, kamus-kamus hukum, jurnal-jurnal hukum, dan komentar-komentar. ${ }^{5}$ Pada penelitian ini yaitu buku-buku terkait tentang Hukum perlindungan konsumen, cybercrime, serta hukum bisnis.

\section{ANALISA DAN PEMBAHASAN}

\section{A. Praktik Periklanan Testimoni Hindi 7 days dan JoyJus Fiber Dalam Media Online Instagram}

Iklan bertujuan untuk memperkenalkan suatu produk kepada masyarakat, selain itu iklan juga digunakan sebagai strategi pemasaran yang bertujuan untuk mengenalkan suatu produk kepada masyarakat. ${ }^{6}$ Transaksi jual beli online terdapat 2 (dua) pihak yang utama yaitu pelaku usaha dan konsumen. Keduanya memiliki hubungan antara satu dengan yang lainnya yaitu penjual dan pembeli. Pelaku usaha dan konsumen dalam UUPK mempunyai hak dan kewajiban yang harus di patuhi. Transaksi online menggunakan media Instagram, website, toko online atau $e$ commerce, dan lain sebagainya.

Jual beli konvensional dan jual beli online sebenarnya sama hanya saja yang membedakan antara jual beli konvensional terletak pada proses mendapatkan barang tersebut misalnya harus keluar rumah terlebih dahulu untuk membeli barang yang diinginkan serta melakukan pembayaran barang tersebut secara langsung yang kemudian barang baru boleh dibawa pulang sedangkan jual beli online dengan menggunakan ponsel klik barang yang akan dipesan diaplikasi yang dipilih melakukan pembayaran yang disediakan aplikasi dan barang akan dikirimkan melalui jasa pengiriman barang (ekspedisi) dalam waktu yang tidak lama barang akan dikirimkan dan diterima oleh konsumen.

Banyaknya transaksi jual beli online kadang dimanfaatkan oleh oknum yang tidak bertanggung jawab untuk melakukan penipuan. Salah satunya dengan melakukan testimoni palsu.

Sosial media menyediakan berbagai macam kemudahan dan tampilan yang menarik untuk dilihat. Media sosial tidak hanya dijadikan sebagai alat komunikasi, memberikan informasi, berita, dan di jadikan media jual beli salah satunya media sosial Instagram. Beberapa orang memanfaatkan Instagram sebagai media jual beli online, salah satunya produk pelangsing yang dijual di Instagram merek Hindi 7 days dan Joyjus Fiber memiliki berbagai macam testimoni dari konsumennya. Produk pelangsing ini tidak hanya menjual melalui Instagram tetapi juga terdapat website didalamnya ditampilkanlah harga produk, manfaat, testimoni dari konsumen, dan info-info terkait produk dan toko online tersebut.

Kriteria iklan yang menyesatkan di media online apabila merujuk pada perspektif hukum positif di Indonesia antara lain yaitu : ${ }^{7}$

1. Iklan yang mengelabui konsumen (misleading) mengenai kualitas, kuantitas, bahan kegunaan, harga, tarif, jaminan dan garansi barang dan/atau jasa dimana pelaku usaha tidak bisa bertanggungjawab dan_memenuhi janji-janji sebagaimana dinyatakan dalam iklan yang disebarkan di media sosial.

2. Mendeskripsikan/memberikan informasi secara keliru, salah, maupun tidak tepat (deceptive) mengenai barang dan/atau jasa, memberikan gambaran secara tidak lengkap (ommision).

3. Memberikan informasi yang berlebihan (puffery) mengenai kualitas sifat, kegunaan, kemampuan barang dan/atau jasa dan membuat perbandingan barang dan/atau jasa yang menyesatkan konsumen.

Testimoni ini diupload melalui aplikasi Instagram untuk menarik konsumen, konsumen yang tidak menyadari adanya kesamaan testimoni antar kedua produk pelangsing ini dapat merugikan dan membahayakan konsumen. Dikatakan "bahaya" karena belum tentu testimoni yang di upload di Instagram tersebut testimoni asli dari produk pelaku usaha tersebut. Pelaku usaha dalam hal ini telah melakukan itikad tidak baik dalam menjual produknya.

Transaksi jual beli online antara penjual dan pembeli harus didasarkan pada prinsip kepercayaan. Pada saat konsumen memilih produk pelangsing dengan melihat iklan testimoni yang sangat meyakinkan namun ternyata iklan

5 Ibid., h. 182

${ }^{6}$ Aulia Muthiah, Hukum Perlindungan Konsumen Dimensi Hukum Positif dan Ekonomi Syariah, Pustaka Baru Press, Yogyakarta, 2018, h. 150

7 Putri Mahadewi. 2016, Perlindungan Hukum Konsumen Atas Tayangan Iklan Televisi yang menyesatkan. Law jurnal, h. 3 
testimoninya sama namun mereknya berbeda. Seperti halnya praktik testimoni sebuah produk pelangsing antara merek Hindi 7 days dan Joyjus Fiber memiliki kesamaan testimoni meskipun merek berbeda meskipun sama-sama menjual produk pelangsing. Hal ini dapat merugikan konsumen atas kenyamanan, keamanan dan keselamatan dalam mengkonsumsi barang dan mendapatkan informasi yang benar, jelas, dan jujur mengenai kondisi dan jaminan barang yang sesuai dengan Pasal 4 huruf a dan huruf c UUPK yang berbunyi:

\author{
"Hak konsumen adalah : \\ a.Hak atas kenyamanan, keamanan, dan keselamatan dalam mengkonsumsi barang dan/atau jasa; \\ b.Hak atas informasi yang benar, jelas dan jujur mengenai kondisi dan jaminan barang dan/atau \\ jasa;"
}

Salah satu kewajiban Pelaku Usaha adalah menjamin informasi yang diberikan melalui iklan testimoni itu harus mengandung unsur kebenaran. Perlindungan hukum dalam UUPK belum pernah diuji sampai ke ranah Pengadilan melainkan terkait sengketa perlindungan konsumen penyelesaiannya secara non litigasi maupun melalui Badan Penyelesaian Sengketa Konsumen (BPSK). ${ }^{8}$ Pelaku usaha harus bertanggung jawab atas produk yang diiklankannya produk yang dijual sudah bersertifikat BPOM, testimoni yang diupload di toko onlinenya benar-benar testimoni asli yang berasal dari konsumen yang mengkonsumsi dan mendapat manfaat dari produknya tersebut, dan lain sebagainya. Hal ini akan berdampak pada kerugian konsumen sebagai pemakai produk tersebut karena tergiur dan secara tidak langsung telah tertipu dengan iklan-iklan dari testimoni yang diupload di toko online penjual tersebut.

Undang-Undang Nomor 19 Tahun 2016 tentang perubahan atas Undang-Undang Nomor 11 Tahun 2008 tentang ITE (selanjutnya disebut UU ITE) Pasal 28 ayat (1) yang berbunyi bahwa:

(1) Setiap Orang dengan sengaja dan tanpa hak menyebarkan berita bohong dan menyesatkan yang mengakibatkan kerugian konsumen dalam Transaksi Elektronik.

Merupakan salah satu ancaman pidana dari Pasal 28 ayat (1) yang dipertegas kembali dalam Pasal 45 ayat (2) UU ITE yaitu penjara paling lama 6 (enam) tahun dan/atau denda paling banyak Rp. 1 Miliar. Dengan demikian, merujuk pada ketentuan pasal tersebut sebenarnya antara pelanggaran-pelanggaran hukum yang dilakukan oleh setiap orang termasuk pelaku usaha yang berkaitan dengan penipuan yang dilakukan secara elektronik yang salah satunya adalah membuat konten-konten atau informasi yang tidak benar atas kegiatan jual beli online maka perbuatan tersebut harus ditindaklanjuti dengan pemberian sanksi pidana terhadap pelaku. Sehingga penegakan hukum perlindungan konsumen bersinergi antara UUPK dengan UU ITE dapat berkolaborasi dalam penegakan hukum yang berkaitan dengan pelanggaran-pelanggaran transaksi jual beli online yang dilakukan oleh Pelaku Usaha.

Ketika iklan memberikan informasi yang menyesatkan seperti halnya testimoni dapat merugikan konsumen, maka para pihak wajib bertanggungjawab. Indonesia belum memiliki peraturan khusus mengenai periklanan, khusunya iklan niaga yang telah berkembang mengikuti era globalisasi dan perkembangan teknologi. ${ }^{9}$ Sedangkan Undang-Undang Nomor 18 Tahun 2012 tentang Pangan, pada Bab VIII Pasal 96 sampai dengan Pasal 100 mengatur tentang label dan iklan pangan. Terdapat suatu kewajiban pada Pasal 100 mengenai label iklan pangan wajib berisikan infomasi yang benar dan jujur, serta melarang para pihak untuk menyampaikan keterangan dan pernyataan yang menyesatkan. Pengawasan terhadap iklan pangan akan diawasi oleh BPOM.

\title{
B. Analisis yuridis hukum perlindungan konsumen dan etika bisnis terhadap praktik periklanan testimoni Hindi 7 days dan Joyjus Fiber dalam media online Instagram
}

Iklan-iklan yang dikonsumsi oleh publik yang produk-produk tersebut dikonsumsi atau digunakan jasanya oleh konsumen. Konsumen yang tertarik dari iklan yang dipublikasikan oleh pelaku usaha mereka akan membeli atau menggunakan jasa yang diiklankan. Pelaku usaha dalam hal ini harus memberikan produk dan jasa yang sesuai apa yang diiklankan. Sesuai dengan Pasal 9 ayat (1) huruf J, dan ayat (2) dan ayat (3) UU PK yang berbunyi :

\footnotetext{
${ }^{8}$ Shidarta, Hukum Perlindungan Konsumen Indonesia,Jakarta: PT.Grasindo,2000, h. 141

9 Dewa Ayu Kade Wida Suryani, Suatra Putrawan, Pertanggungjawaban selebgram terhadap konsumen yang mempromosikan barang dan jasa di media sosial, Jurnal Kertha Semaya, Vol.8 No. 6 Tahun 2020, h. $922-932$
} 
Website : http://yustisia.unmermadiun.ac.id/index.php/yustisia

(1) Pelaku usaha dilarang menawarkan, mempromosikan, mengiklankan suatu barang dan/atau jasa secara tidak benar dan seolah-olah:

j. menggunakan kata-kata berlebihan, seperti aman, tidak berbahaya, tidak mengandung resiko, atau efek sampingan tanpa keterangan lengkap;

(2) Barang dan/atau jasa sebagaimana yang dimaksud pada ayat (1) dilarang untuk diperdagangkan

(3) Pelaku usaha yang melakukan pelanggaran terhadap ayat (1) dilarang melanjutkan penawaran, promosi, dan pengiklanan suatu barang dan/atau jasa tersebut

Iklan yang mengandung kesamaan kata testimoni dengan produk berbeda seperti yang terdapat dalam produk Hindi 7 days dan Joyjus Fiber dalam media online Instagram dapat menyesatkan konsumen yang akan membeli produk pelangsing ini, testimoni yang dipublikasikan di Instagram apakah benar testimoni asli produk tersebut ataukah ternyata testimoni tersebut adalah milik produk orang lain yang digunakan oleh oleh pelaku usaha lain untuk iklan produknya. Produk yang dijual oleh pelaku usaha yang mempunyai testimoni sama akan mengakibatkan kurangnya jaminan keselamatan kepada konsumen dan keraguan terhadap jaminan manfaat dan fungsi dari produk tersebut. Larangan pelaku usaha ini dalam UUPK merupakan perbuatan melanggar hukum dan berakibat pelaku usaha akan dikenakan sanksi baginya.

Pasal 17 ayat (1) huruf C dan ayat (2) UU PK mengatur terkait larangan pelaku usaha periklanan yaitu :

(1) Pelaku usaha periklanan dilarang memproduksi iklan yang :

c. Meтuat informasi ya ng keliru, salah, atau tidak tepat mengenai barang dan/atau jasa; pernyataan yang salah;

(2) Pelaku usaha periklanan dilarang melanjutkan peredaran iklan yang telah melanggar ketentuan pada ayat 1.

Iklan merupakan salah satu bentuk informasi kepada konsumen dari bentuk barang atau jasa agar produknya dikenal oleh masyarakat. Masyarakat memperoleh gambaran tentang produk yang diiklankan pelaku usaha melalui iklan. Masalah-masalah iklan tidak selamanya memberikan informasi yang benar atau lengkap terhadap suatu produk, sehingga konsumen dapat menjatuhkan pilihannya kepada suatu produk tertentu berdasarkan informasi yang tidak lengkap tersebut. ${ }^{10} \mathrm{Hal}$ ini akan mengakibatkan kerugian kepada konsumen.

Pelaku usaha mempunyai tugas dan kewajiaban untuk menjaga dan menciptakan iklim usaha yang sehat dan menunjang perekonomian nasional. Pelaku usaha harus mempunyai tanggung jawab atas pelaksanaan tugas dan kewajiban itu dengan menerapkan norma-norma hukum, kepatutan dan menjunjung tinggi didalam dunia usaha. Pelaku usaha dalam dunia perdagangan harus mempunyai pedoman dalam melakukan etika bisnis. Prinsip business is business ini tidak dapat digunakan karena prinsip ini digunakan dalam prinsip bisnis untuk pembangunan. Pelaku usaha harus menjaga keseimbangan antara pelaku usaha dan konsumen yang saling menguntungkan dengan memberikan produk dan jasa sesuai dengan apa yang diiklankan.

Pasal 7 angka 1 UU PK, kewajiban pelaku usaha harus senantiasa beritikad baik untuk menciptakan iklim perdagangan yang sehat untuk menunjang pembangunan nasional yang saling bersinergi antara konsumen dan pelaku usaha. Ketentuan dalam UU PK bermaksud mengarahkan pelaku usaha untuk berperilaku sedemikian rupa dalam rangka mensukseskan pembangunan ekonomi nasional khususnya dibidang usaha. Kewajiban pelaku usaha memberikan informasi yang benar, jelas dan jujur mengenai kondisi dan jaminan barang dan.atau jasa serta memberi penjelasan penggunaan, perbaikan, dan pemeliharaan disebabkan karena informasi disamping merupakan hak konsumen, juga karena ketiadaan informasi yang tidak memadai dari pelaku usaha merupakan salah satu jenis cacat produk artinya terdapat cacat informasi yang akan sangat merugikan konsumen. Masalah-masalah periklanan diatur dalam Pasal 8 sampai dengan Pasal 16 UU PK dan khusus di dalam Pasal 17 UU PK mengantur perbuatan yang dilarang bagi pelaku usaha.

Larangan pelaku usaha dalam UU PK membawa akibat bahwa pelanggaran atas larangan tersebut dapat dikualifikasikan sebagai perbuatan melanggar hukum. Adanya UU PK ini dapat membantu untuk menciptakan iklim perdagangan yang sehat serta melindungi konsumen dari produk-produk yang diperjualbelikan melalui iklan agar tidak melanggar hukum. Bentuk tanggung jawab bagi pelaku usaha dalam bentuk kompensasi yaitu berupa ganti kerugian yang dialami konsumen. Terdapat dalam Pasal 19 ayat (2) UU PK memberikan pedoman mengenai jumlah, bentuk, serta wujud ganti kerugian, yaitu: pengembalian uang, penggantian barang atau jasa sejenis yang

${ }^{10}$ Ahmadi Miru dan Sutarman Yodo. Hukum Perlindungan Konsumen. Raja Grafindo Persada. Jakarta. 2004, h. 104 
Website : http://yustisia.unmermadiun.ac.id/index.php/yustisia

sepadan nilainya, perawatan kesehatan, dan pemberian santunan sesuai dengan ketentuan perundang-undangan yang berlaku.

Tanggung jawab untuk memberikan ganti kerugian tidak semata-mata diberikan pelaku usaha yaitu dengan syarat konsumen dapat membuktikan secara nyata memang konsumen dirugikan atas barang atau jasa yang digunakan setelah melihat iklan yang dipasang oleh pelaku usaha. Pasal 20 UU PK juga mengatur mengenai tanggung jawab pelaku usaha periklanan atas iklan yang diproduksi dan seluruh dampak yang diakibatkan atas iklan tersebut.

Periklanan yang mengunakan media sosial yaitu Instagram produk Hindi 7 days dan Joyjus Fiber yang menggunakan testimoni yang sama dengan produk berbeda. Hal ini melanggar Pasal 28 ayat (1) UU ITE yang berbunyi :

(1) Setiap Orang dengan sengaja dan tanpa hak menyebarkan berita bohong dan menyesatkan yang mengakibatkan kerugian konsumen dalam Transaksi Elektronik.

Sedangkan menurut Pasal 28 ayat (1) UU ITE ini diberlakukan ancaman bagi pelaku dengan sanksi pidana sebagaimana diatur dalam Pasal 45A ayat (1) UU ITE berbunyi :

Setiap Orang yang dengan sengaja dan tanpa hak menyebarkan berita bohong dan menyesatkan

yang mengakibatkan kerugian konsumen dalam Transaksi Elektronik sebagaimana dimaksud

dalam Pasal 28 ayat (1) dipidana dengan pidana penjara paling lama 6 (enam) tahun dan/atau

denda paling banyak Rp1.000.000.000,00 (satu miliar rupiah).

Selain merujuk pada peraturan perundang-undangan terkait perlindungan konsumen atau peraturan-peraturan lainnya yang relevan dengan kasus tersebut diatas bahwa tindakan pelaku usaha produk pelangsing Hindi 7 days dengan Joyjus Fiber memang secara aturan hukum maupun etika bisnis yang baik adalah tidak benar. Selain bersifat menyesatkan dengan adanya informasi yang tidak benar dengan mengelabuhi konsumen dengan cara memberikan testimoni produk yang sama padahal produknya berbeda, hal ini sudah tidak sesuai dengan etika dalam berbisnis yang baik dan benar. Etika berbicara mengenai suatu perilaku atau sikap yang baik. Namun kenyataannya dengan adanya pengelabuhan testimoni tersebut menjadikan konsumen percaya terhadap iklan yang tidak benar atau sesat tersebut. Terkait kode etik periklanan berisikan bahwa iklan harus jujur, bertanggung jawab dan tidak bertentangan dengan hukum yang berlaku. ${ }^{11}$ Dengan demikian, perbuatan pelaku usaha produk pelangsing Hindi 7 days dengan Joyjus Fiber telah melanggar baik aturan hukum dan tidak sesuai dengan etika bisnis yang baik dan benar.

\section{KESIMPULAN}

Dari beberapa uraian pembahasan yang telah dipaparkan para peneliti sebagaimana tersebut diatas, dapat ditarik suatu kesimpulan antara lain sebagai berikut :

1. Praktik testimoni produk pelangsing Hindi 7 days dan Joyjus Fiber pada media iklan melalui Instagram adalah tidak benar dan menyesatkan karena testimoni yang digunakan kedua produk pelangsing tersebut adalah sama padahal kedua produk tersebut adalah merek yang berbeda dan dari pelaku usaha yang berbeda pula. Tentu tindakan periklanan kedua produk tersebut merupakan tindakan pengelabuhan produk yang bertujuan menyesatkan dan memberikan informasi yang tidak baik dan tidak benar.

2. Praktik testimoni produk pelangsing Hindi 7 days dan Joyjus Fiber dalam perspektif hukum perlindungan konsumen merupakan perbuatan melanggar ketentuan hukum Pasal 17 ayat (1) huruf C dan ayat (2) UU PK juncto Pasal 28 ayat (1) UU ITE yang mana perbuatan tersebut dapat dikenakan sanksi berupa sanksi hukum sedangkan dalam perspektif etika bisnis, kedua pelaku usaha produk pelangsing tersebut tentu tidak menerapkan prinsip-prinsip etika berbisnis yang baik dan benar karena dengan sengaja menggunakan testimoni produk yang bertujuan mengelabuhi konsumen sehingga dapat mengakibatkan kerugian terhadap konsumen.

\footnotetext{
${ }^{11}$ Laila, Khotbatul. "Perlindungan HukumTerhadap Konsumen Atas Iklan Yang Melanggar Tata Cara Periklanan”,Jurnal Cakrawala Hukum 8, No. 1 2017, h.66
}

Volume 7 Nomor 2 September 2021, YUSTISIA MERDEKA | 84 
Website : http://yustisia.unmermadiun.ac.id/index.php/yustisia

\section{DAFTAR PUSTAKA}

Ahmadi Miru dan Sutarman Yodo. Hukum Perlindungan Konsumen. Raja Grafindo Persada. Jakarta. 2004

Aulia Muthiah, Hukum Perlindungan Konsumen Dimensi Hukum Positif dan Ekonomi Syariah, Pustaka Baru Press, Yogyakarta, 2018

Celina Tri Siwi Kristiyanti, Hukum Perlindungan Konsumen, Sinar Grafika, Jakarta, 2009

Peter Mahmud Marzuki, Penelitian Hukum (Edisi Revisi), PT. Adhitya Andrebina Agung, Jakarta,2015

Shidarta, Hukum Perlindungan Konsumen Indonesia,Jakarta: PT.Grasindo,2000

Susanti Adi Nugroho, Proses Penyelesaian Sengketa Konsumen Ditinjau dari Hukum Acara Seraya Kendala Implementasinta, Kencana, Jakarta, 2011

\section{Jurnal}

Dewa Ayu Kade Wida Suryani, Suatra Putrawan, Pertanggungjawaban selebgram terhadap konsumen yang mempromosikan barang dan jasa di media sosial, Jurnal Kertha Semaya, Vol.8 No. 6 Tahun 2020

Laila, Khotbatul. "Perlindungan HukumTerhadap Konsumen Atas Iklan Yang Melanggar Tata Cara Periklanan”,Jurnal Cakrawala Hukum 8, No. 12017

Putri Mahadewi. Perlindungan Hukum Konsumen Atas Tayangan Iklan Televisi yang menyesatkan. Law jurnal, 2016

\section{Peraturan Perundang-undangan}

Undang-Undang Perlindungan Kosumen Nomor 8 Tahun 1999 tentang Perlindungan Konsumen ( Tambahan Lembaran Negara Republik Indonesia Nomor 3821);

Undang-Undang Nomor 19 Tahun 2006 tentang Perubahan Atas Undang-Undang Nomor 11 Tahun 2008 tentang Transaksi elektronik (Tambahan Lembaran Negara Republik Indonesia Nomor 5952)

Peraturan Pemerintah Nomor 58 Tahun 2001 tentang Pembinaan dan Pengawasan Penyelenggaraan Perlindungan Konsumen. 